\title{
The Analysis of Investment, Labor, Exports, Exchange Rate's Effect toward the Indonesian Economic Growth
}

\author{
Akmal Umar ${ }^{1}$ \\ (iD) \\ Sekolah Tinggi IImu Manajemen Indonesia (STIMI) \\ Makassar, Indonesia (High School of Management \\ Sciences of Indonesia Makassar, Indonesian)
}

\begin{abstract}
This study aimed to analyze the effect partially and simultaneously of the investment variable, the labor variable, the export variable, and the rate / value of the rupiahs variable toward the Indonesian economic growth. The whole data used in this research are secondary data from the systematic recording in the form of time series data (time series) in the period of 2007 to 2013 which were obtained from the Central Statistics Agency (BPS) of South Sulawesi Province. Model analysis of the data in this study is using multiple linear regressions with ordinary least squares approach (OLS). The results of this study indicate that in period of 2007 - 2013, the partially variables: Investment has no effect to economic growth; Labor positively and significantly affected to economic growth; Export in this case net-exports a negatively and significantly affected to economic growth; and the rupiahs' exchange rate has not affected economic growth. And simultaneously variables: Investment, Labor, Exports, Foreign Exchange positively affected to Indonesia's Economic Growth.
\end{abstract}

Keywords: Investment, Labor, Exports, Exchange rate, Economic growth.

\section{Contents}

1. Preface. 249

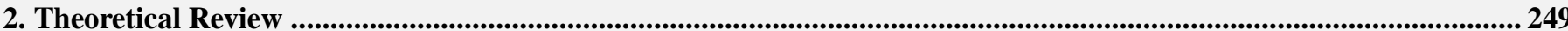

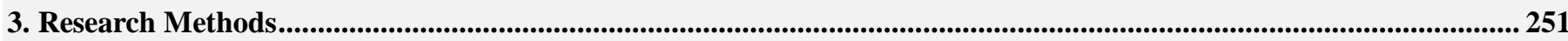

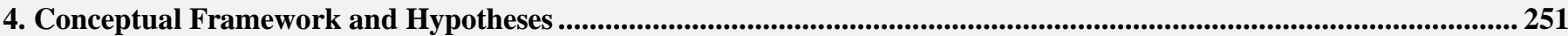

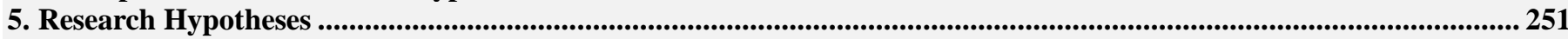

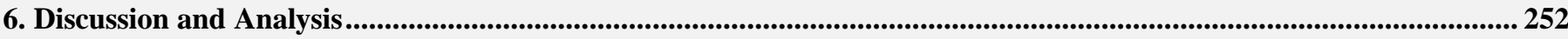

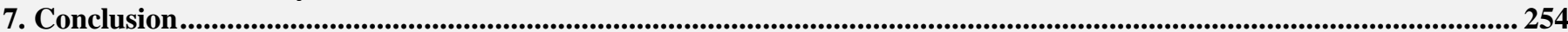

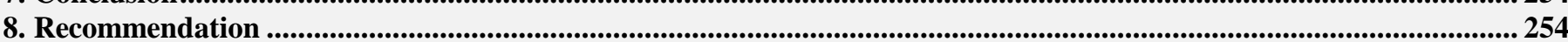

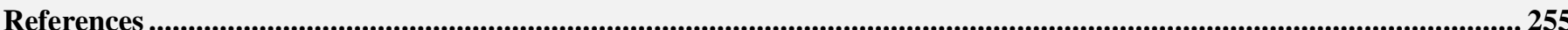

Citation | Akmal Umar (2016). The Analysis of Investment, Labor, Exports, Exchange Rate's Effect toward the Indonesian Economic Growth. Asian Journal of Social Sciences and Management Studies, 3(4): 248-255.

DOI:

ISSN(E):

10.20448/journal.500/2016.3.4/500.4.248.255 Crossref

ISSN(P):

$2313-7401$

$\operatorname{ISSN}(\mathbf{P}):$

Funding:

Competing Interests:

This work is licensed under a Creative Commons Attribution 3.0 License $((c))$

Transparency:

The author declares that there are no conflicts of interests regarding the publication of this paper.

The author confirms that the manuscript is an honest, accurate, and transparent account of the study was reported; that no

Ethical: vital features of the study have been omitted; and that any discrepancies from the study as planned have been explained This study follows all ethical practices during writing.

History:

Publisher: $\quad$ Asian Online Journal Publishing Group 


\section{Preface}

A country can be known has a good economic condition through the calculations of high economic growth, or simply measured by the increasing of goods and services produced. The indicator of goods production and services numbers on economic is known as Domestic Bruto Products (DBP) terminology, that DBP is used to measure the economic growth level based on constant prices (real DPB) to eliminate the effects of price changing along the measurement's period of time.

In a country, the economic growth is a priority achievement. They would do many ways and economic strategies that could support the economic growth level achieved. It would become an overview welfare and wealth level for every citizen who lived in that country.

The economic growth is the average of increasing output that produced by everyone in goods and services production which are the growth levels per capita in real terms for everyone. Since this increment, it is hoped would increase the capital production of each labor or in other words it would increase foreign exchange reserves (Shone, 1989).

Based Todaro (2000) the economic growth is one of indicators of a country's economic progress. It is the increase in the capacity in a long term of its country to provide various economic goods to their people/citizen. There are three main factors in economic growth; first, accumulation of capital which are through all kinds and types of new investments implantation, physical implementation, assets and human resources; second, the population growth which would multiply the numbers of labor force; and third, advanced technology.

Next is based on Sukirno (2002) the economic growth is an important thing for a nation, the problems of economic growth are become the nation's purposes to improve national development which could improve human quality and its community. The economic growth is not apart from labor, and technology, they are necessary to support neither economic growth, nor job opportunities. In actualizing economic growth, Indonesia needs two important factors, there are assets and expertise. The availability of assets is not enough to improve the economic, it necessarily needs expertise, well-educated and skilled in production process, this labor needs education and training due to the ability improvements. Besides, the entrepreneur development needs to be improved too, the entrepreneur's faction is very important to decide where are the economic development would be achieved. They are the factions of borrower or raise the capital/ assets or own funds who would develop production process activities (Sukirno, 2004).

The government has an important role in economic because they're in charged as a regulator (controller). Besides, the government as a simulator, the government's funds could be used as a stimulant to manage private investment or general public towards the direction that government wanted to, both in terms of the activity and the location (Tarigan, 2005).

The policy which has been run by the governments is the policy that should be able to overcome the economic problems overall. In the other side could increasing exports as a foreign exchange's producer to financing the imports, also the interest payment and the foreign debt, and on the other hand could curb inflation. This curb inflation is directed to prevent the decrease in consumer purchasing power, especially of the majority who consume lots of basic needs, but in the other hand is also a powerful implement to maintain the competitive exchange rates to support exports, and can solve problems in the field of employment (Mubyarto, 2000).

From the previous explanation could be seen that investment, labor, exports, and exchange rates are indicated Indonesia's Domestic Bruto Products (DBP) growth, which is assumed partially and simultaneously has been affected to Indonesia's economic growth.

\section{Theoretical Review}

Harrod-Domar's theory in Dornbusch and Fisher (2004) this economics theory analyzes the relationships between growth level and inflation level. The idea is that at a certain level of national income is sufficient to absorb all workers, with wage level in the next period would no longer sufficient to absorb all the existing all workers. This occurs because of the additional production capacity in the initial period and available in the following period. Thus required the additional funds to achieve the absorption level of full employment in the next period, by calculating the relationship between capital (capital stock $=\mathrm{K}$ ), with the production result (output $=\mathrm{Y}$ ), or with a capital output ratio (COR).

From this theory, it could be concluded that there is a direct economic relationship between the amount of capital stock $(\mathrm{K})$ and output $(\mathrm{Y})$, which is formulated on Capital Output Ratio (COR). $\mathrm{K}$ is a value from all entire capital goods such as land, building, implements, and materials, while $\mathrm{Y}$ can be measured by gross national income or gross national product. The higher the capital stock increased, the higher the output produced. In this concept said that as a cause of investment which has been done, in other time the capacity of capital goods in the economy would grow, and that all available capital goods fully in used, the aggregate demand must be increased by the increase in the capacity of capital goods were realized as a result of past investments. It seems that the need for capital investment in creating economic growth, or to enhance the economic growth required new investment is a net addition to the capital stock (Mankiw, 2003).

Solow's Growth Model (Solow, 2007) basically this model is the development of Harrod-Domar formulations by adding the second factor, which is labor, and also introducing the independent variable, the third is technology into equality growth. Different as Harrod-Domar's model which assume constant return scale by default coefficients, neoclassic Solow's mozdel holds on concept of diminishing returns from labor input and capitals if both of them analyzed separately; if both of them analyzed together, Solow also used that constant return to scale. Technological advances designated as residual factor to explain the economic growth in the long term, and high and low growth itself by Solow and the other theoretical assumed exogenous, or not influenced by other factors.

Sollow's growth model also shows how savings, population growth, advanced technology affected economic output level and its growth all the time. This model was designed to show how growth in capital stock, growth in labor market, and advanced technology interacting in economy eventually affecting a country's goods and service output overall (Mankiw, 2006). 
There are three main factors in economic growth: first, capital accumulation, which conclude all forms or types of new investments implantation, physics implementation and assets or human resources; second, the population growth which next few more years would multiply the numbers of labor force; and third, advanced technology (Todaro, 2000).

From all the third factors of economic growth is concluded that source of economic progress may include all types of factors. Generally could be said that the main resource of economic growth is investment which is able to fix up the capital's quality and human \& physical resources that would increase productivity resources and physical quality which could increase the productivity of all resources through new inventions, innovation, and technology advanced (Salomo, 2007).

The connection between investment and economic growth as is investment as the purchase of goods / capital and production equipment in increasing the ability of goods and services productivity which is needed in economy would increase the real Indonesia Domestic Bruto Products (DBP) and therefore would have positive effect towards economic growth (Handayani, 2011). The raise of investment would increase production capacity that would lead to the new job opportunities, which on the next level would encourage the economic growth (Sutawijaya, 2010).

Based on Suparmoko (2004) there are some theories that could explain how big the investment level which can be worked to accelerate the economic growth in a country or an area: (1) Gradualist Theory, this theory point of view is that the least developed countries should not quickly industrialize because of the risk and mistakes would be too great to bear. Capital injection that much is not good until the economy is able to absorb it. Production selection techniques and investment are based on relative costs than production factors. It should be attempted to advance small industries, the development of villagers that use extra labor. The activity which needs a lot of capitals would attempt if the profits exceed labor intensive; (2) Big Push theory, this theory briefly said that if there's a little effort to raise incomes, it only encourages the population growth alone that would obstruct the increase in per capita income.

Therefore, the efforts should be implemented on a large scale to cope with changes in the population. The implication is to be held massive investments to eliminate poverty, maximizing the output using the most productive technique that sometimes requires huge capital. This is concentration on investment which in turn produced tools and capital to sustain the income growth in output. Consumption otherwise suppressed, so that investment can continue to exist.

The emphasis on "economies of scale" in the form of large scale production and of course also requires a lot of capital; (3) Theory of Balanced Growth, the theory was first proposed by Rosenstein-Rodan in 1953 which emphasize that the economy is likely to grow if there is a good balance between the various sectors in the economy. With the balanced growth is interpreted that economic development will not succeed if the investment was limited to the specified growing point or sectors that is growing just because other sectors are closely related. Investments should be spread across all sectors thereby expanding the market from one sector to the other sectors. The closer the relationship of interdependence between the various sectors, the market will get stronger. To realize this theory certainly should be supported by a substantial investment; (4) The Unbalanced Growth Theory, the theory proposed by Hirschman in 1992 which initially criticized the theory of balanced development. He said that the community in still low income level cannot change the system of traditional economy into a modern system. Besides, the great capital cannot be provided by the State that is still develops. It is precisely the lack of balance will encourage faster economic progress and expansion costs can be minimized. When one sector remains low output, it will remain in demand in other sectors and there would be super-normal profits in the sector's low output.

According to Todaro (2000) population growth and labor force growth is traditionally regarded as one of the positive factors that accelerate economic growth. The greater amount of labor means will increase the level of production, while the greater population growth means a larger size of its domestic market.

Lewis in Todaro (2004) the homogeneous and unskilled labor force is considered to be able to move and shift from the traditional sector to the modern sector smoothly and in limited quantities. These circumstances, labor supply contains a high elasticity. Increased demand for labor (from the traditional sector) root in the expansion of modern sector activities. Thus one of the factors that influence the economic growth is labor.

In macroeconomic theory, the relationship between exports with the level of economic growth or national income is an identity equation because exports are part of the national income level (Oiconta, 2006). From the point of the expenditure, exports are one of the most important factors in the Gross National Product (GNP) so that with a change in the value of exports, the income of the community directly will also undergo changes. On the other hand, higher a country's exports would cause the economy will be very sensitive to the fluctuations in the international markets and the world economy (Irham and Yogi, 2003).

Associated with the relationship between exports and economic growth, Jung and Marshaall (1985) suggest that the relationship between exports and economic growth, there are at least four hypotheses or views that are equally plausible, and acceptable. First, the hypothesis that exports as the motor for economic growth (export-led growth hypothesis). Secondly, the hypothesis that is exports are the cause lowers economic growth (export-reducing growth hypothesis). Third, the hypothesis is the export rather than a motor for economic growth in the country, but on the contrary of domestic economic growth is an activator for export (internally generated export hypothesis). Lastly, the fourth is the hypothesis that economic growth is a factor caused the exports decrease (growth-reducing export hypothesis).

Santoso (2010) in his research concluded that simultaneous variable import of capital goods, investment, labor, and foreign exchange significantly affect Indonesia's economic growth. However, partial variable imports of capital goods, exports, and investment, labor, and foreign exchange rates did not affect the economic growth in Indonesia.

In a study of the international trade role as a source of economic growth in Indonesia, Salomo (2007) concluded that in the long term real exports, real imports, the real exchange rate, the number of workers, and the crisis a significant effect on economic growth. 


\section{Research Methods}

This study uses descriptive and quantitative analysis. Descriptive analysis is used to describe the phenomena related to the problem under the study, whereas quantitative analysis is used to analyze the quantitative information.

The data used in this research is secondary data obtained from the systematic recording compaction in the form of time series from the year 2007 to 2013 were obtained from the Central Statistics Agency (CSA) of South Sulawesi Province. Furthermore, the data were analyzed using multiple regression approach to ordinary least squares (OLS).

Data analysis method:

$$
\begin{aligned}
& \begin{array}{l}
\mathrm{Y}=\mathrm{f}\left(\mathrm{X}_{1}, \mathrm{X}_{2}, \mathrm{X}_{3}, \mathrm{X}_{4} \ldots \ldots \ldots \ldots . . . . .\right. \\
\mathrm{e}^{\mathrm{Y}}=\beta_{0} \mathrm{X}_{1}{ }^{\beta 1} \mathrm{X}_{2}{ }^{\beta 2} \mathrm{X}_{3}{ }^{\beta 3} \mathrm{X}_{4}{ }^{\beta 4} \mathrm{e}^{\mu}
\end{array} \\
& \text { Where: } \\
& \mathrm{Y}=\text { Economic Growth }(\%) \\
& \beta_{0} \quad=\text { Constant Numeral } \\
& \beta_{1} \beta_{2} \beta_{3} \beta_{4}=\text { Regression Coefficients } \\
& \mathrm{X}_{1} \quad=\text { Investment } \\
& \mathrm{X}_{2} \quad=\text { Labor } \\
& \mathrm{X}_{3} \quad=\text { Exports } \\
& \mathrm{X}_{4} \quad=\text { Exchange Rates }(\mathrm{Rp} / \$) \\
& \mathrm{e}=\text { exponential number } \\
& \mu \quad=\text { term of error }
\end{aligned}
$$

\section{Conceptual Framework and Hypotheses}

Economic growth is a process of increase in real gross national product, or an increase in real national income. Economic changes can occur, both growth, static or decrease in real national income. Growth is a positive change, whereas a decrease is negative changes.

Investment is defined as the expenses for the purchase of capital goods and equipment production with the purpose of replacing and specially to increase the capital goods economy, which would be used to produce goods and services in the future. If the value of the investment is positive, then the gross domestic product (GDP) is positive, will further increase the GDP growth as well as expanding the business field, increase national income and improve the prosperity of society.

The use of labor in the production process related to the costs of production and wages. Both in terms of production costs and the level of wages, employment related to increased labor productivity and returns that production factor received. With the increasing number of workers, it will increase labor productivity as a result of changes in the quantity and quality of labor itself in order to encourage economic growth.

Net exports is the value of a country's exports minus its imports, exports are one of foreign exchange source. To be able to export, the State should be able to produce goods and services in international markets. Net exports which earned by a country would have a positive impact on economic growth if the value of exports is greater than the value of imports, thus improved its national income and stimulate economic growth.

The exchange rate is one factor that affects the trade balance, if the domestic exchange rate depreciated it would increase the volume of exports so that the trade balance surplus, and vice versa.

The conceptual framework of this research is showed at Figure 1 below:

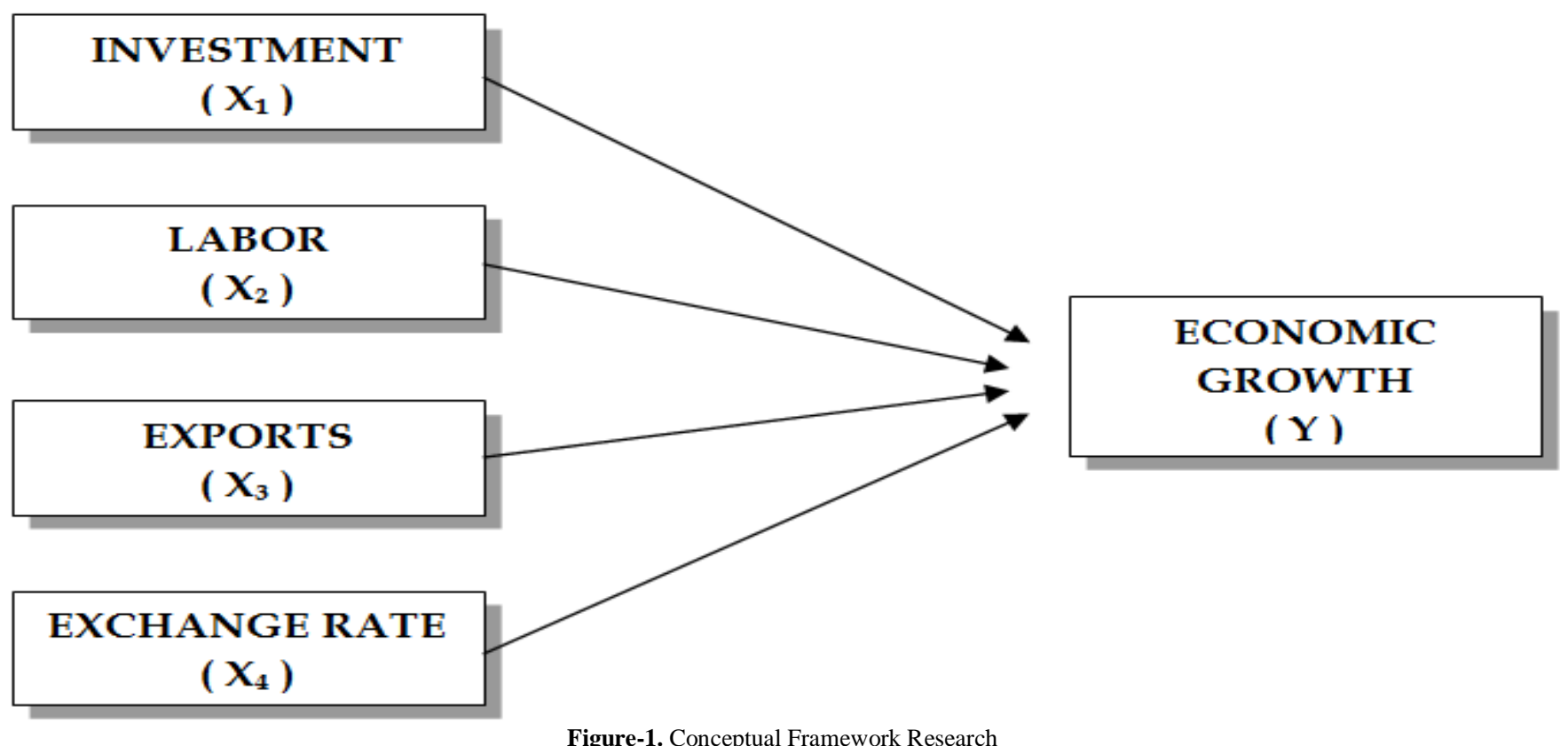

Source: Author

Figure-1. Conceptual Framework Research

\section{Research Hypotheses}

H1: Investment positively affects on Economic Growth

H2: Labor positively affects on Economic Growth

H3: Exports positively affects on Economic Growth

H4: Exchange rates positively affects on Economic Growth 
H5: Simultaneously Investment, Labor, Export, Exchange Rate positively affects on the Economic growth.

\section{Discussion and Analysis}

\subsection{The Influence of Investment towards Economic Growth}

The investment is an activity to transform the potential resources into real economic strength. The development of the investment value of Indonesia in the period of 2007 - 2013, both investment Domestic Investment (DCI), as well as Foreign Direct Investment (FDI) is fluctuating increase and decrease. Table 1 below shows the decreasing and the increasing of investment value in Indonesia in the period of 2007-2013.

Table-1. The Development of Indonesia's Investment Year of 2007 - 2013

\begin{tabular}{l|l|l|l|l}
\hline Year & DCI (billion Rp) & Trend (\%) & FDI (million US\$) & Trend (\%) \\
\hline 2007 & 34878.70 & & 10341.40 & \\
\hline 2008 & 20363.40 & $(-) 41,62$ & 14871.40 & $(+) 43,80$ \\
\hline 2009 & 37799.90 & $(+) 85,63$ & 10815.20 & $(-) 27,28$ \\
\hline 2010 & 60626.30 & $(+) 60,39$ & 16214.80 & $(+) 49,93$ \\
\hline 2011 & 76000.70 & $(+) 25,36$ & 19474.50 & $(+) 20,10$ \\
\hline 2012 & 92182.00 & $(+) 21,29$ & 24564.70 & $(+) 26,14$ \\
\hline 2013 & 128150.60 & $(+) 39,02$ & 28617.50 & $(+) 16,50$ \\
\hline
\end{tabular}

Source: Central Statistics Agency (CSA) of South Sulawesi

Based on the investment value of Indonesia in Table 1 shows that the value of both domestic investment and FDI fluctuated. In 2007 the value of domestic investment and FDI is quite high, supported macroeconomic stability quite well after the economic crisis. This encourages economic growth. In 2008, the value of domestic investment decreased by $41.62 \%$, which resulted from the impact of the global crisis, while the value of foreign investment increased by $43.80 \%$, this is due to the improvement in investor perceptions and increased return on investmen. Subsequently in 2009 , the value of domestic investment increased sharply by $85 \%$, while the value of foreign investment decreased by $27.28 \%$. Furthermore, between 2010 and 2013 there was an increase the value of the average domestic investment amounted to $36.52 \%$, while the FDI increasing in investment value of average of $28.17 \%$.

Based on multiply regression analysis by OLS approached, regression coeficient investment is 0.010 isn't significant with the significancy level $\alpha=0.538 \%$, it means that investment smally affected (not significant) towards Indonesia's economic growth. When the investment increase $1 \%$, then the ecnomic growth would increased only $0.010 \%$.

The analysis and implication of investment effect towards Indonesia's economic growth that both DCI and FDI investment in period of 2007 - 2013 have contributed towards Domestic Bruto Products (DBP) were not too affected, so it has been impacted to the small DBP's changes.

This study is not appropriate with hypotheses which concluded in Harrod-Domar theory gives the key to investment in economic growth process, especially about investment multiply roles, which are: first, investment creates income, and second, the investment enhanced economy production capacity by increased the capital stock.

Implantation domestic capital proportion and implantation foreign capital in DBP and investment rapid growth didn't mean that ecoomic growth run well and vice versa, because the important thing is not besarnya investment in money value or the number of projects, but how the efficiency and productivity from its investment.

\subsection{The Influence of Labor Towards Economic Growth}

Labor usually called as "manpower" is one of supported factors the used of other production factors that would be used in production process, even the most important factor than the other factors because human is a motor of all production factors exist.

Labor is one of production factors in economy, in other side, labor is also one part of citizen who produce goods and services.

Indonesia labor growth are generally increase in period of 2007 - 2013. Table 2 below shows the number of labor in Indonesia in period of $2007-2013$.

Table-2. Indonesia Labor Growth Year 2007 - 2013

\begin{tabular}{l|l|l}
\hline Year & Labor (million people) & Trend $(\%)$ \\
\hline 2007 & 109.94 & \\
\hline 2008 & 111.95 & $(+) 1,83$ \\
\hline 2009 & 113.83 & $(+) 1,68$ \\
\hline 2010 & 116.53 & $(+) 2,37$ \\
\hline 2011 & 117.37 & $(+) 0,72$ \\
\hline 2012 & 118.05 & $(+) 0,58$ \\
\hline 2013 & 121.19 & $(+) 2,66$ \\
\hline \multicolumn{2}{l}{ Source: Central Statistics Agency (CSA) of South Sulawesi }
\end{tabular}

Table 2. shows that the number of Indonesia labor growth generally incrased annualy in period of $2007-2013$. In year 2007 the number of labor is 109.94 million people, next on 2008 the number of labor increased to 111.95 million people, increase as much as $1,83 \%$. on the next years the number of labor keep increased, the biggest increasing was in year 2013, it was increase as much as 2,66\%, with the number of labor into 121.19 million people.

Based on multiply reggression analysis with OLS approach, reggression coefficient of labor is 2.783 significantly with the significant level $\alpha=0.000 \%$, this indicates that there's positive relationship between labor 
variable with Indonesia economic growth. It means when the labor has increased 1\%, therefore economic growth would increase $2.783 \%$.

The analysis and implication of labor effect towards Indonesia economic growth show that in the period of 2007 - 2013 the number of labor significantly affected towards Indonesia economic growth, or in other words the econmic growth as overviewed as DBP supported by tgw growth or the increasing the labor numbers. This study parallel with the result study of Santoso (2010) that the labor variable is real affected simultantly towards Indonesia economic growth.

\subsection{The Effect of Exports towards Economic Growth}

Exports are a total of goods and services that have been sold by a country to the others, includes the insurance, and any services in a particular year.

Nett exports are the exports total reduced by the imports total, Nett exports are very affected toward income and stimulate economic growth, if the nett exports value are positive, it means the exports value is bigger than the imports value, and if the nett exports are negative, it means that the exports value is smaller ahn the imports value (Case and Fair, 2009). If the exports netto are positive, it would increase the nationl income, otherwise if the netto exports are negative, it would decrease national income.

Here is a picture of the Indonesia nett exort growth in the period of 2007 - 2013, are presented in Table 3.

Table-3. Indonesia Net Exports Growth Period of 2007 - 2013

\begin{tabular}{l|l|l|l|l}
\hline Year & Exports Value (US\$) & Imports Value (US\$) & Nett Exports Value (US\$) & Trend (\%) \\
\hline 2007 & $114,100,890,751$ & $74,473,430,118$ & $39,627,460,633$ & \\
\hline 2008 & $137,021,424,402$ & $129,197,306,224$ & $7,823,118,178$ & down 80,26 \\
\hline 2009 & $116,510,026,081$ & $96,829,244,981$ & $19,680,781,100$ & up 151,57 \\
\hline 2010 & $157,779,103,470$ & $135,663,284,048$ & $22,115,819,422$ & up 12,37 \\
\hline 2011 & $203,496,620,060$ & $177,435,555,736$ & $26,061,064,324$ & up 17,84 \\
\hline 2012 & $190,031,845,244$ & $191,691,001,109$ & $-1,659,195,865$ & Nett-exp (-) \\
\hline 2013 & $182,551,794,701$ & $186,628,669,880$ & $-4,076,875,179$ & Nett-exp (-) \\
\hline
\end{tabular}

Table 3. shows that Indonesia nett-exports value in the period of $2007-2013$ experienced a fluctuating trend, even in last a couple years 2012 and 2013 Indonesia nett-exports value were negative (exports value were smaller than imports value).

In 2008 Indonesia nett exports decreased by $\$ 7.823$ million (80.26\%) compared with the nett-exports in 2007, this was caused by the world global crisis. Subsequently in 2009 with the improvement in the global economy bring a positive influence, nett-exports recur increased by $151.57 \%$ with a nett exports value amounted to $\$ 19.681$ million.

In 2010 the increase of nett exports only 12.37 with the exports value of \$ 22.116 million. Furthermore, in 2011 the value of nett-exports rose by $\$ 26.061$ million or $17.84 \%$. But in 2012 and 2013 nett-exports was negative, exports decreased drastically, while the value of imports increased.

Based on the multiple regression analysis with OLS approach, the regression coefficient of nett-exports mounted to -0.001 , significantly with the significance level $\alpha=0.029 \%$. It means that the nett-exports variable significantly is negatively related to the Idonesia economic growth in the period of $2007-2013$. When the nett-exports rose $1 \%$, economic growth would decreased by $0.001 \%$.

This study is in line with the findings of Aliman and Purnomo (2001) stated that export is a causes of the decline economic growth (export-reducing growth hypothesis).

However, it is incompatible and does not match with the theory of international trade by Heckscher et al. (1991) which states that the nett-exports is one of the most important factors of Gross National Product (GNP), so that with the change in the value of the nett exports, it will influence the change of the national income. Similarly with the of Salomo (2007) that in long term net-exports is significantly affected the economic growth. And Oiconta (2006) which states that in a certain analysis period obtained overall has relationship effect of nett exports towards GNP or economic growth.

\subsection{The Effect of Exchange Rates towards the Economic Growth}

The rupiah exchange rate is a comparison of the value or price of the rupiah to the price of the other currency. In trade between countries each country has its own instrument exchange rate that would require comparative figures for the value of a currency with another currency called foreign exchange rates or exchange rates (Salvatore, 2008).

This exchange rates is one of the indicators that affect the activity in the stock market and financial markets, as investors tend to be cautious to invest. The decline in the rupiah exchange rate against foreign currencies, especially the US dollar had a negative effect on the economy and capital markets (Sitinjak and Kurniasari, 2003).

If the exchange rate depreciates, the value of domestic currency decreased and imply foreign currency exchange rates are getting higher, it will cause exports increased and imports decreased. And vice versa in case of currency appreciation in the value of domestic currency increases, it will cause exports decreased and imports are likely to increase.

Thus foreign exchange rates have a direct relationship with the exports volume. If the value of the dollar exchange rate increases, the volume of exports will also increase (Sukirno, 2002).

The development of the exchange rate during the period of $2007-2013$ were fluctuated and tended to depreciate over the years. These fluctuations are caused by several factors, both fundamental factors such as supply and demand for foreign currencies, as well as non-fundamental factors, namely political and security developments in the country.

Since 1997 introduced a system of floating exchange rates, the position of rupiah exchange rate against foreign currencies, particularly the US \$ was determined through market mechanisms, so that the rise and fall of the 
exchange rate was determined by market forces. The pressures on the rupiah resulted in the rupiah exchange rate becomes too low (undervalued).

Here is a picture of the development of the exchange rate in the period 2007-2013, is presented in Table 4.

Table-4. Indonesia Exchange Rates Development Period of 2007 - 2013

\begin{tabular}{l|l|l}
\hline Year & Exchange Rates $(\mathbf{R p} / \mathbf{\$})$ & Trend $(\%)$ \\
\hline 2007 & 9.419 & \\
\hline 2008 & 10.950 & $(+) 16,25$ \\
\hline 2009 & 9.400 & $(-) 14,16$ \\
\hline 2010 & 8.991 & $(-) 4,35$ \\
\hline 2011 & 9.057 & $(+) 0,73$ \\
\hline 2012 & 9.638 & $(+) 6,41$ \\
\hline 2013 & 10.452 & $(+) 8,45$ \\
\hline
\end{tabular}

Source: Central Statistics Agency (CSA) of South Sulawesi

From the Table 4. illustrated that the rupiah exchange rates changed in the period of $2007-2013$. In 2007 the exchange rate was in a position of less than Rp 10,000 per US \$ in the amount of Rp 9,419 per US \$. And in 2008, the rupiah weakened to Rp 10,950 per US \$, so in the year 2009 to 2012 the exchange rates was fluctuated below Rp 10,000 per US $\$$. Furthermore, in 2013 there was an increase in oil prices and the poor condition of the world economy makes the exchange rate weakened into the position of Rp 10,452 per US \$.

Based on the multiple regression analysis by OLS approach, the regression coefficient of the exchange rates amounted to -0.044 is insignificantly $\alpha=0.538 \%$, showing a number greater than $\alpha=5 \%$. It may be mentioned that the variable rates has no effected (negative but not significant) to economic growth in Indonesia.

The results of this study indicate that the fluctuations in the exchange rates of $\mathrm{Rp} / \mathrm{US} \$$ during the period of 2007 - 2013 did not give a significant effect on the national economy of Indonesia. This is due to the national economic growth driven more by spending for the governments and private consumption.

The results of this study are consistent with the results of Ditha (2011) which states that the exchange rate or the exchange rate against the US dollar did not significantly affect the variables of economic growth in Indonesia.

While the results of this study are not correspond with the opinion of Sarwono and Perry (1998) that if it is linked by exchange rate channel in the monetary policy mechanism, the movement in the exchange rate may affect the open economy by a flexible exchange rate system. But the reality of the results of this study showed the opposite.

\subsection{The Influence of Independent Variables towards Research Dependent Variables}

Based on tests conducted to analyze how much influence the independent variables namely investment (X1), labor (X2), exports (X3), and the exchange rate (X4) on the dependent variable is economic growth (Y), using the equation analysis of linear, then obtained a constant value of 1.653. It means if without the influence of the independent variables, the rate of economic growth in Indonesia was 1,653 percent.

From processing SPSS shows the determination coefficient $\mathrm{R} 2=0.993$, means that the independent variables are able to explain the dependent variable variation of 99.3 percent, or in other words there is only a 0.7 percent were influenced by other factors which not included in the the explanatory variables.

Analysis of Variance (Test-F) shows that F count $=380.265$ while $\mathrm{F}$ table -2.60534 , thus the four independent variables jointly has significant effect on the dependent variable.

It can be concluded that simultaneous independent variables (investment, employment, exports, and foreign exchange) significantly affected on economic growth in Indonesia (the dependent variable).

\section{Conclusion}

From the discussion result of this study can be drawn the conclusion that the five hypotheses proposed in the research on Indonesia's economic growth in the period of 2007 - 2013, as follows: (1) The investment has no effect towards economic growth, if there is an increase or decrease in the investment does not affected the economic growth, thus it means that $\mathrm{H} 1$ is rejected; (2) Labor positive and significant effect on economic growth, if there is an increase in the number of labor, it will provide a real influence on economic growth, thus it means the $\mathrm{H} 2$ is accepted; (3) Exports in this case the nettt-export a significantly has negative effect towards economic growth, if there's an increase in nett exports, it has no effect towards economic growth, or growth will decreased, thus H3 is rejected; (4) The rupiah exchange rate has no effect on economic growth, if there's an increasing or decreasing in the exchange rate, will have no impact towards economic growth, thereby H4 rejected; (5) Simultaneously Investment, Labor, Export, Exchange Rate positively affected towards economic growth, or four independent variables jointly significant effect on the dependent variable, thus H5 accepted.

\section{Recommendation}

Based on the conclusions of this research, there are some suggestions to the Indonesian government: (1) give special attention to the size of the investment contribution to Gross Domestic Product (GDP), in this study it was found that the reviews largest contribution to GDP is dominated by private consumption and government spending. So the growth of investment was not able to give a significant impact towards the increasing GDP; (2) improving the quality of employment by developing system were coherence between education, skills training commensurate with the needs of the labor market, development and technology development; (3) holding of export diversification in order to the net-exports have contributed positively towards the economic growth, and so that not only fixed on primary products which have less added-value and competitive value in world market; (4) to maintain the exchange rate to remain stable, with a stable exchange rate is expected to give a positive impact on the economic climate, especially in terms of international trade activities. 


\section{References}

Aliman and Purnomo, 2001. Kausalitas antara Ekspor dan Pertumbuhan Ekonomi. Jurnal Ekonomi dan Bisnis Indonesia, 16(2): $122-137$.

Case, K.E. and R.C. Fair, 2009. Principles of economic. New York: Prentice Hall.

Ditha, R.K., 2011. Analisis pengaruh Investasi, inflasi, Nilai Tukar Rupiah Dan Tingkat Suku Bunga Terhadap Pertumbuhan Ekonomi Di Indonesia. Thesis. PPS Universitas Brawijaya Malang.

Dornbusch, R. and S. Fisher, 2004. Macroeconomics. 6th Edn., New York: McGraw-Hill. Inc.

Handayani, T., 2011. Faktor-faktor Yang Mempengaruhi Pertumbuhan Ekonomi di Indonesia Periode 1999 - 2008. Yogyakarta: Universitas Pembangunan Nasional "Veteran".

Heckscher, E.F., O. Bertil and Heckscher-Ohlin, 1991. Trade theory, translat-ed, edited, and introduced by Harry Flam and M. June Flanders, Cambridge, Mass: MIT Press.

Irham and Yogi, 2003. Ekspor di Indonesia, Pustaka Binaman, Cetakan Pertama. Jakarta: Pressindo.

Jung, W. and P. Marshaall, 1985. Exports, growth and causality in developing countries. Journal of Development Economics, 18(1): 1 - 12.

Mankiw, G.N., 2006. Teori makroekonomi. 6th Edn., Jakarta: Erlangga.

Mankiw, N.G., 2003. Teori makro ekonomi terjemahan. Jakarta: PT. Gramedia Pustaka Utama.

Mubyarto, 2000. Membangun sistem ekonomi. Yogyakarta: BPFE.

Oiconta, N., 2006. Analisis Ekspor dan output nasional di Indonesia: Periode 1980 - 2004 Kajian Tentang Kausalitas dan Kointegrasi. Thesis. Universitas Indonesia, Jakarta.

Salomo, R., 2007. Peranan perdagangan Internasional Sebagai salah satu sumber pertumbuhan ekonomi Indonesia. Modul. Departemen Perdagangan RI dan Program Pascasarjana Ilmu Ekonomi Universitas Indonesia, Jakarta.

Salvatore, D., 2008. Theory and problem of micro economic theory. Alih bahasa oleh rudi sitompul. 3rd Edn., Jakarta: Penebit Erlangga.

Santoso, R.T.T., 2010. Analisis Perdagangan Luar Negeri Terhadap Pertumbuhan Ekonomi di Indonesia. Skripsi. Universitas Pembangunan Nasional "Veteran", Jawa Timur.

Sarwono, H.A. and W. Perry, 1998. Mencari Paradigma Baru Manajemen.

Shone, R., 1989. Open economy macroeconomics. London: Harverster Wheasheaf.

Sitinjak, E.L.M. and W. Kurniasari, 2003. Indikatorindikator Pasar Saham dan Pasar Uang yang Saling Berkaitan Ditinjau dari Pasar Saham Sedang Bullish dan Bearish. Jurnal Riset Ekonomi dan Manajemen. Universitas Sumatera Utara, 3(3): 156-177.

Solow, R.M., 2007. The last 50 years in growth theory and the next 10. Oxford Review of Economic Policy, 23(1): 3-14.

Sukirno, S., 2002. Ekonomi pembangunan proses masalah dan dasar kebijaksanaan. Jakarta: UI-Press.

Sukirno, S., 2004. Makroekonomi teori pengantar. Jakarta: PT Raja Grafindo Perkasa.

Suparmoko, M., 2004. Pengantar ekonomi makro. Yogyakarta: BPFE.

Sutawijaya, A., 2010. Pengaruh Ekspor dan Investasi Terhadap Pertumbuhan Ekonomi Indonesia Tahun 1980 - 2006, Jurnal Organisasi dan Manajemen, Jakarta.

Tarigan, R., 2005. Ekonomi Regional,Teori dan Aplikasi. Ed Revisi. Jakarta: Bumi Aksara.

Todaro, M.P., 2000. Pembangunan Ekonomi. Haris Munandar. Jakarta: Penerbit Erlangga.

Todaro, M.P., 2004. Pembangunan Ekonomi. Haris Munandar. Jakarta: Penerbit Erlangga. 